\title{
A Heideggerian Critique of Immersive Art
}

\author{
Harri Mäcklin
}

\begin{abstract}
Immersive art has been one of biggest trends in the artworld for the past few years. Yet, so far there has been little philosophical discussion on the nature and value of this immersive trend. In this article, I show how Heidegger's meditations on art can provide a robust assessment of immersive art. On the one hand, immersive art can be taken to culminate in Heidegger's views on the "machinational" character of modern art, where artworks turn into calculative experience machines, geared to provide "lived experiences" rather than experiences of truth. On the other hand, Heidegger's thought also lends itself to a more positive assessment, where immersive art undermines machination from within and provides experiences of wonder, which are irreducible to and uncontrollable by calculative thinking.
\end{abstract}

KEYWORDS: art, immersion, lived experience, machination, wonder

CONTACt: Department of History, Philosophy, and Art Studies, University of Helsinki; harri.macklin@helsinki.fi

Gatherings: The Heidegger Circle Annual 11 (2021): 64-92. 


\section{INTRODUCTION}

For the past decade or so, immersion has been perhaps the biggest buzzword in contemporary art. Experiences of being transported to another world have become a desired goal not just in the visual arts, but also in theater, cinema, and musical performances. By immersive art, I refer to artworks that produce holistic environments the perceiver enters rather than viewing them as objects from the outside. These environments can be solely physical spaces, digitally produced virtual realities, or a mix of physical and digital elements - what is essential is the experience of being inside another world. ${ }^{1}$ Though immersive art as such is not a recent invention - just think of Yayoi Kusama's Infinity Mirror Rooms from the 1960s, James Turrell's Skyspaces from the 1970s, or Pipilotti Rist's video installations from the 199os - the development of recent digital technologies has created a veritable boom in its popularity. With new technologies, such as virtual reality and augmented reality devices, $3^{\mathrm{D}}$ projections, multichannel video installations, and tracking cameras, artists are able to create more holistically enveloping and interactive environments than ever before.

All this has had a dramatic impact in the artworld. Artists specializing in immersive art, such as the Japanese collective teamLab and the Meow Wolf company in the us, have become stars in the contemporary art scene. Several exhibitions on immersive art have been organized in the past years around the globe, and special venues dedicated to immersive art, such as the Mori Art Museum in Tokyo, the Atelier des Lumières in Paris, and the Otherworld in Ohio, have also opened their doors. Immersive exhibitions are often reported to draw large audiences, with people willing to queue for hours for the opportunity to see teamLab's installations or spend just a minute or less inside Kusama's Mirror Rooms. ${ }^{2}$ All in all, immersion has gained an increasingly significant role in the way art is made, exhibited, and experienced - and we have no reason to believe that this will be just a passing trend.

What are we to make of this development? So far, philosophical aesthetics has had rather little to say about the immersive trend in art. ${ }^{3}$ In art journalism, on the other hand, the reception of immersive art has 
been mostly skeptical. The main worry is that immersivity has become a self-serving purpose, with art focusing increasingly on the production of extraordinary experiences instead of dealing with current issues and engaging with the surrounding world. Some critics view immersive artworks as being mere visual rollercoasters or backgrounds for Instagrammable selfies, others question whether we should call them art at all. Immersive artworks have been called "infantilized," "a perversion of traditional art with a glaringly commercial intention," "fleeting entertainment," and "circus tricks," ${ }^{18}$ among other things. The consensus, it seems, is harsh: immersive art is symptomatic of art's decline into superficial entertainment that replaces the communication of ideas with spectacles and swanky selfies.

In this article, I suggest that Martin Heidegger's meditations on art offer a starting point for a robust philosophical approach to immersive art. Heidegger's engagement with art presents a complex diagnosis according to which art is intimately affected by the ills of modernity but is also pregnant with the possibility of overcoming those very ills. I aim to show how these meditations can be used to give substance to the dominant criticisms of immersive art - and also to undermine them. On the face of it, Heidegger's thinking seems to play neatly into the claim that immersive art trades in empty spectacles; however, I also argue that immersive art's capacity to create experiences of wonder and to thematize its own technological condition make it well disposed to fill the role Heidegger gives art in the contemporary world. Thus, my claim is that Heideggerian thinking allows us to see immersive art as a more ambivalent and complex phenomenon than what the dominant critical discourses lead one to believe. This conclusion also opens an interesting possibility in Heideggerian philosophy of art: whereas existing commentaries seem to suggest that art in the era of modernity can be either a source of pleasurable experiences or preparation for the return of the gods, my suggestion is that immersive art can, paradoxically, represent both at the same time - that it harbors both danger and saving power within itself (cf. GA 7: 29/QCT 28). Perhaps needless to say, the following considerations are "Heideggerian" in spirit only, for the 
simple reason that Heidegger himself has, for obvious reasons, nothing to say about contemporary immersive art and very little about immersion in general. ${ }^{9}$ Nonetheless, my intention is to show how Heidegger's claims need hardly any extrapolation to help us interpret the nature and value of immersive art.

My effort to interpret the immersive trend through a Heideggerian lens is not just aimed at understanding immersive art better. This article is motived by an overarching desire to assess the usefulness of Heidegger's thinking for the philosophical theorization of contemporary art in general. Much has changed since the 1930s, when Heidegger produced the main bulk of his writings on art, and it is not altogether clear how applicable his views are to the contemporary artworld. ${ }^{10}$ Given the central position that Heidegger's thinking as a classic of modern art theory has, it is surprising how little contemporary research questions whether Heidegger's thinking is still relevant for theorizing contemporary art. Furthermore, the publication of Heidegger's Black Notebooks and the following debates on his anti-Semitism, as well as the perceived radical conservatism of his thought, ${ }^{11}$ have made him an increasingly problematic figure in the humanities. The applicability of his works in the contemporary world is far from self-evident. As I cannot discuss these overarching issues here, my more modest aim is to show that Heideggerian philosophy of art is well equipped to illuminate the ambiguities of contemporary immersive art, thus giving us a reason to believe in the continuing relevance of his thought for at least some phenomena in contemporary art.

I will first discuss how immersive art fits into Heidegger's view of modern art as Erlebniskunst, i.e. art that aims at "lived experiences" (Erlebnisse) instead of world-disclosure. I will then offer a reading of Heidegger's account of the affinity between "machination" (Machenschaft) and modern art, most fully formulated in Mindfulness (1938-39), and claim that immersive art epitomizes this relationship. Lastly, I will counterbalance this negative assessment by searching the Heideggerian corpus for more positive ways of approaching immersive art, especially in view of Heidegger's discussions on wonder. 
A few caveats are in order. Immersive art, like art in general, is not a homogeneous category, and it is difficult if not impossible to make overarching claims that would apply to all immersive artworks. What interests me here is the general tendency in contemporary immersive art to use digital technologies to produce holistic, otherworldly spectacles with little or no further content. On a more exegetical note, this article is not an exercise in the chronological interpretation of Heidegger's thinking. Rather, it aims to see how Heidegger's meditations on art as a whole might expand toward an artform he himself did not address.

\section{IMMERSION, LIVED EXPERIENCE, AND MACHINATION}

In order to understand what role immersive art might have from a Heideggerian perspective, we need to begin by outlining Heidegger's view on art's place in modernity. This view is summarized in Heidegger's enigmatic claim that "we [modern people] do not have any art...we do not know what art 'is' - we do not know if one day art could once more be - we do not know if it has to be."12 Echoing Hegel's famous dictum that for us moderns, art is "a thing of the past" (ein Vergangenes) ${ }^{13}$ Heidegger's meditations start with the conviction that, in modernity, art has lost the role it had in earlier epochs. The claim that "we do not have any art" does not mean that the production of pieces of art (Kunststücke) has ceased, but that they have ceased to function as artworks (Kunstwerke) in the specific sense in which Heidegger understands the term (GA 80.2: 565-66). As outlined in "The Origin of the Work of Art" (1935-36), a work of art - or "great art" (große Kunst), at least - means a "happening of truth" (Geschehnis der Wahrheit) (GA 5: 24.PLT 37). A great work makes

manifest, in the way appropriate to works, what beings as a whole are, preserving such manifestation in the work. Art and its works are necessary only as an itinerary and sojourn for man in which the truth of beings as a whole, that is, the unconditioned, the absolute, opens itself up to him. (GA 6.1: 82/N1 84) 
The greatness of a Greek temple, for example, lies in its capacity to thematize the meaning structures of the Greek world (die Welt) as well as to bring forth the earth (die Erde) upon which it stands (GA 5: 27-33/ PLT $40^{-4} 6$ ). The "world" denotes here the meaning structures that inform the Greeks of their own identity, their gods, and their place in the cosmic order; the earth, by contrast, denotes the material, sensuous, and elemental basis that sustains the world. By setting up the world and setting forth the earth, the temple functioned as a measure ( $M a \beta)$ that helped the Greeks to position themselves in the world in relation to their gods and their destiny (GA 5: 29-30/PLT 42-43). A great work of art is, so to speak, onto-ethical: it indicates to a historical people who they are, where they live, and how they should live their lives.

But then, in the dawn of modernity (die Neuzeit), the relationship of human beings to art began to change (GA 6.1: 81-82/N1 83-84). This change was part of a larger development in which human beings' relation to the world and themselves began to be informed by technoscientific thinking, subjectivism, and the universalizing tendencies of modern science. Here humans begin to posit themselves as the relational center of the world, so that other beings become objects - Gegenstände, something facing them - whose being is measured against human will to power (GA 5: 87-88/QCT 127-28). In earlier epochs, humans saw themselves as belonging to a greater scheme of things, an order that exceeds their control (GA 5: 9o/QCT 130), but with the breakthrough of modern subjectivism, "there begins that way of being human which mans [sic] the realm of human capability as a domain given over to measuring and executing, for the purpose of gaining mastery over that which is as a whole" (GA 5: 92/QCT: 132). As a result of this change, "beings became disenchanted [entzaubert] and explained as something calculatively controllable and transparent" (GA 80.2: 614); higher purposes, or "gods," ceased to guide the human sojourn in the world, leaving no "measure" to bridle the endeavor to control all things.

One reason for this disappearance of measures was that art, too, became reinterpreted in modern thought in the form of aesthetics. In Heidegger's usage, aesthetics - like metaphysics - has a very distinct 
meaning: it refers to a particular historical space of thinking that delimits possible ways of approaching beauty and art, namely, the "consideration of the beautiful to the extent that it stands in relation to man's state of feeling" (GA 6.1: $75^{-7} 6 / \mathrm{N} 178$ ). In other words, aesthetics names a form of thought in which art is evaluated in terms of its beauty, which, in turn, is understood in terms of the sensuous feelings it arouses in the perceiver. The former onto-ethical role of art is now replaced with the goal of producing "lived experience" (Erlebnis). In the epilogue of "Origin," Heidegger writes:

Lived experience is the source that is standard not only for art appreciation and enjoyment, but also for artistic creation. Everything is a lived experience. Yet perhaps lived experience is the element in which art dies. The dying occurs so slowly that it takes a few centuries. (GA 5: 67/PLT $77 \mathrm{tm})$

By approaching an artwork as a source of lived experience, the perceiver posits herself as the relational center of the engagement and evaluates the work on the basis of its capacity to elicit feelings that enhance her life (GA 65: 129). This comportment fundamentally changes the experiential character of art. Witnessing the happening of truth in great art is, in Heidegger's descriptions, a mixture of unsettlement, awe, and cosmic gratitude, something reminiscent of the classic aesthetic notion of sublimity. ${ }^{14}$ When the artwork is subjugated as a source of lived experience, it becomes secure and tame, unable to disturb the perceiver's sense of security and power. In this way, art moves "to the area of the pastry chef" (GA 4.0: 140) - becomes something as trivially pleasurable as a piece of cake.

In Heidegger's history of aesthetics, this "peculiar calamity" (merkwürdiges Verhängnis) (GA 80.2: 619) of the aesthetic approach to art began in the theories of Plato and Aristotle, but remained ineffective up to the birth of modernity, when theory turned into practice and the classical relationship to art was severed (GA 6.1: $78-83 / \mathrm{N} 18 \mathrm{o}-84) .{ }^{15} \mathrm{Art}$ ceases to be great and "forfeits its essence, loses its immediate relation 
to the basic task of representing the absolute, i.e., of establishing the absolute definitively as such in the realm of historical man" (GA 6.1: 83/N1 84). When Heidegger hyperbolically says that modernity has no art, he means that it has no great art because modernity makes no "space" for such art. ${ }^{16}$

Now, what does all this mean for immersive art? Let us return to the topic of lived experience. An often-repeated criticism claims that immersive art tends to favor epic, mind-blowing experiences over deep insight; as the art historian Felicity Scott has it, immersive art harnesses and reflects "the contemporary desire for...spectacular forms of exposure." ${ }^{17}$ Immersive art is a prime example of art becoming increasingly caught up in the logic of experience production - or, in more contemporary terms, of the "experience economy." Take, for example, Kusama's classic Infinity Mirror Rooms. People are willing to queue for hours for a chance to step inside small, mirror-covered rooms that expand into infinite spaces of flickering lights and polka dots. It seems that whatever value such artworks have, it is based on their ability to create extraordinary experiences. Heidegger would surely have identified immersive art as belonging to, or even culminating in, the modern development of art as Erlebniskunst.

This claim finds some echoes in Heidegger's assessment of Richard Wagner. In his Nietzsche lectures (Will to Power as Art, 1936-37), Heidegger argues that Wagner attempted to revive great art in the form of opera, which unites all artforms into a Gesamtkunstwerk, but his approach was inappropriate for achieving such a communitarian goal: Wagner does not conceive of art in terms of truth disclosure but in terms of lived experience. The mythological narratives of the Wagnerian operas became a mere means by which music can elicit intense experiences. Here art turns into theatrics (Theater), in which "all portrayal is to work its effects as foreground and superficies, aiming toward the impression, the effect, wanting to work on and arouse the audience" (GA 6.1: 85/N1 86). The desired effect, furthermore, is "the dissolution of everything solid into a fluid, flexible, malleable state, into a swimming and floundering; the unmeasured, without laws 
or borders, clarity or definiteness; the boundless night of sheer submergence" (GA 6.1: 86/Ni 87). In a similar way, the contents of immersive artworks are usually not there to inspire thinking but rather to serve as a setting for spectacular experiences. It is thus not difficult to see a similar apotheosis of lived experience in immersive art as in Wagner's operas.

From the late 1930s onwards, Heidegger's meditations on art become intimately tied to his views on the techno-scientific and nihilistic nature of the modern age. Machination names the modern human being's dominant world-relation, where beings are approached as something to be controlled, calculated, and used as a resource of human will to power (GA 66: 16/12). The environment and other beings are subjugated under coercive thought that "fosters in advance the completely surveyable calculability of the subjugating empowering of beings to an accessible arrangement" (GA 66: 17/12). Such a world-relation represents, in Heidegger's view, the completion of the metaphysical tradition that has guided Western thought from its inception in Greek philosophy.

Drawing from Hölderlin's poetry, Heidegger calls the current world situation a "destitute time" (dürftige Zeit) (GA 5: 269/PLt 89), "night" (GA 52: 87/77), or the "winter" (GA 4: 109/132) of the world's history. In "What Are Poets For?" (1946), Heidegger argues that this time is characterized by "the default of God" (der Fehl Gottes), by which he means the absence of higher purposes to position human beings in the world and to measure their manner of dwelling: "no god any longer gathers men and things unto himself, visibly and unequivocally, and by such gathering disposes the world's history and man's sojourn in it" (GA 5: 269/PLt 89). Because the gods are absent, there is no collective ethos to give measure to machinational thinking, and the West has thus become fragmented into factions of unrestrained will to power without any sense of holiness. ${ }^{19}$

In late modernity, art falls prey to machinational thinking, becoming itself a mode of machination. This change manifests itself in the following ways: 1) art becomes a way of manipulating beings and organizing the masses, 2) it promotes certain modes of experience and 
comportment that reinforce the human sense of control vis-à-vis beings, and 3) art turns from world-disclosure into technical world-constitution. My claim is that all these aspects are emphatically present in immersive art.

I. Manipulating beings and organizing the masses. In Mindfulness, Heidegger has the following to say about the effect of machination on art:

What art brings forth is...not works in beyng-historical sense that inaugurate a clearing of beyng... What art brings forth are "installations" (forms of organizing beings).... Word, sound and image are means for structuring, stirring, rousing and assembling of masses, in short, they are means of organizing. (GA 66: $3^{1 / 24}$ tm)

Here art's turning toward lived experiences gains a sinister twist. Instead of letting beings come to presence on their own accord, machinational art approaches beings as something manipulable with the goal of producing lived experiences and "organizing the public life of the masses" (GA 66: 32/24). Heidegger continues:

Productions of art generally have the character of "installation" which is already guided by a pre-ordained direction of a surpassing that plans and produces the beings that are to be controlled - a pre-ordained direction which is never to become explicit but should "organically" "fit" into the "landscape," into the public needs and measures. (GA 66: $3^{2 / 25}$ )

Heidegger identifies two elements that define machination's grasp on art: installation (Anlage) and training-in-lived-experience (Erlebnisschulung) (GA 66: $3^{2^{-}} 34 / 25^{-26}$ ). The former refers to the way machinational art functions, and the latter to the product of this functioning. The English translation of Anlage as "installation" might lead one to assume that Heidegger is here speaking specifically of installation art, which usually means three-dimensional site-specific artworks, but the original German term means, among other things, "a factory," "a 
technical appliance," or "a system." Heidegger's somewhat ambiguous use of the term seems to play on these technical associations, but mainly he emphasizes the connotation of "plan." Instead of letting beings come forth in their truth, machinational art becomes a calculated tool for organizing the masses and controlling their experiences. For example, Heidegger argues that cinema is an effective tool in promoting certain societal comportments, fashions, and gestures (GA 66: 31/24). At the same time, machinational art teaches us to value and expect extraordinary experiences, so that the uncommon and amazing becomes a norm we use to evaluate art; "we might think in passing of all the extraordinary things the cinema must offer continually," Heidegger observes (GA 45: 158/137). This thirst for amazement, which art itself installs on us, turns art into kitsch, in which "the very best skill... is devoted to what is empty and is not fundamental" (GA 66: 31/24). In Heidegger's estimation, kitsch supersedes what in previous eras was "ownmost" to art to the extent that "kitsch becomes autonomous and no longer experienceable as kitsch," i.e. becoming our conception of art as such (GA 66: 31/24). Here the metaphysical determination of art becomes complete (GA 66: 30/23). "The sign of this [completion]," Heidegger writes, "is the disappearance of the work of art but not art itself" (GA 66: 30/23). A mere tool for the machinational organizing of humans and other beings, art loses its relevance as a history-directing power, as a place of decision (Entscheidung) (GA 66: 35/27).

It is easy to see how immersive art exemplifies art's turning into machinational kitsch. By drawing huge audiences and attracting visitors who would not otherwise be interested in art, immersive art functions as an ample way of organizing and manipulating the masses. Immersive art relies as much as Wagnerian opera on "theatrics" to create maximally mind-blowing experiences and providing opportunities for Instagram-worthy photos.

In this way, immersive artworks turn into experience machines. Take, for example, Hannes Koch's and Florian Ortkrass's installation Rain Room (2012), where visitors walk through a downpour of rain without getting wet. With the use of 3D tracking cameras, the installation's 
program monitors the visitors' movements and stops the flow of water above them. When entering the Rain Room, visitors interact

with a field of data processed by invisible electronic circuits (for which their bodily movements serve as input) whose visual and acoustic expression or output is a spatiotemporal, three-dimensional matrix of droplets. What they encounter is information embedded in, or materialized as, water. ${ }^{20}$

The Rain Room exemplifies how, through digital technologies, artworks turn into fields of data processing that are geared to manipulate the visitor's environment and their experience of it. This very same technology can also be used to collect data on the audiences' reactions inside the installation, making it possible to optimize the work's functioning along the way. ${ }^{21}$ The experiences we get from such works are not the result of letting beings come to presence in their truth, but the product of fine-tuned calculation. Immersive artworks could thus be portrayed as mere machines in the service of distributing machinational thinking and installing Erlebnis-based modes of experience.

2. Promoting a sense of security and control. As we have already seen, modern art, in Heidegger's view, does not aim at the disclosure of truth but at the production of lived experiences that do not threaten the perceiver's secure position in the world. But in Mindfulness, the aim of machinational art is not simply to produce lived experiences but to train humans to approach everything in terms of the enhancement of life:

"Training-in-lived-experience"...means honing in on everything by taking and assessing everything entirely according to what machinationally sways in beings (itself hidden and ungraspable). This means: no longer searching "behind" or "above" beings, not even feeling "emptiness," but searching and finding, exclusively and maximally, what in the enactment of the machinational is "liveable" [Er-lebbare], and as such can be incorporated into one's "own" "life" - which is shaped 
by the masses - and thus to foster this as what is solely valid and assuring. (GA 66: 33/25-26)

Why does machination promote lived experiences? First of all, lived experiences give the impression of compensating for the impoverishment of machination, rescuing us from the cold, calculative character of modern life (GA 6.1: 87/Ni 88). However, this attempt of compensation is itself a mode of machination. When art is approached as a source of lived experience, its power to make us aware of the forces that guide our comportment is rendered impotent and it becomes a mere source of innocuous sensory pleasure. Instead of indicating man's place in a larger scheme of things, the artwork becomes another tool in machination's attempt to confer "upon him the appearance of self-assertion vis-à-vis beings" (GA 66: 17/13), that is, the belief that human beings can subjugate everything under their own will. The Rain Room, again, exemplifies this beautifully: it takes the natural phenomenon of rainfall and, through technical control, removes from it the discomfort of getting wet.

3. World-disclosure becomes world-constitution. As I noted earlier, the greatness of an artwork is measured in the Heideggerian picture by its capacity to bring to light usually unnoticed meaning structures of the world it belongs to. Heidegger notices how modern art seems to have an impulse to leave the lifeworld ${ }^{22}$ behind in favor of creating whole new worlds - for example, he comments on how abstract art exemplifies art's integration in "the sphere of techno-scientific world-construction" (GA 10: 31). Photography and cinema, Heidegger also argues, have their essence not in world-disclosure but in machination's idea of "the all-producing and all-constituting makability of beings" (GA 66: 31/24). With new digital technologies, immersive art takes this world-constitution to a completely new level. Immersive artworks are not objects that stand against a background of the lifeworld, but holistic environments that allow the visitor to momentarily leave the lifeworld behind and step into another world. Such works do not light up the lifeworld but occlude it. At the same time, they strengthen the machinational illusion that "everything man encounters exists only insofar as it is his construct" 
(GA 7: 28/QCT 27), that man is not only able to manipulate what already exists but is able to create something ex nihilo.

In Mindfulness, Heidegger points to how the epoch of machination, which he refers to as "the completion of modernity" (die Vollendung der Neuzeit), also brings to completion the metaphysical, that is, "aesthetic" character of art. In other words, machinational art is the end product of over two millennia of development through which art's relation to truth-disclosure is slowly severed, rendering art merely a source of lived experiences and a tool for securing power. By showing how seamlessly immersive art fits into Heidegger's descriptions, we can even venture to claim that immersive art, with its inclination toward vacuous spectacles and its apotheosis of technically manipulated and produced worlds over the actual, historical world, represents the culmination of art's turning into machination.

\section{A HEIDEGGERIAN APOLOGY FOR IMMERSIVE ART}

While I have painted a somewhat grim picture of immersive art as machinational art par excellence, one wonders whether Heidegger's thinking could also lend itself to a more positive assessment. I do think that the current critical discourse, as well as the Heideggerian elaboration presented above, amply capture some of the problems present in current practices in immersive art. However, I also think that a one-sidedly negative stance toward immersive art misses some positive aspects that enrich our understanding of the artform. Indeed, I will claim that immersive artworks can be argued to have two positive traits. First, the marvelous experiences they afford can grow into wonder; second, they can make us mindful of the hold machination has on us. In this way, I claim, immersive art proves to be a more ambivalent and complicated phenomenon than the current critical discourse - and my discussion so far - makes it out to be.

As Julian Young has pointed out, Heidegger himself came to realize in the late 1930s that the "Greek paradigm" he uses to assess current art is problematic in the sense that no art in the modern world achieves the onto-ethical role he is seeking - neither Cézanne nor Klee, whom 
he came to admire later in his life, nor even his beloved Hölderlin. ${ }^{23}$ This insight injected a certain ambiguity into Heidegger's relationship to modern art. On the one hand, he continues to insist that he does not see how modern art could be "pointing a path" (Wegweisende) for us. ${ }^{24}$ On the other hand, he begins to adopt what Young calls "the modern paradigm of art," where modern art gains a new mission: preparing for a change that leads to the other onset. ${ }^{25}$ Such art could be viewed as being, if not great, at least "valid" in that it shines some light of hope amid the ever-darkening night of the world. It is precisely this new paradigm that, I think, also gives us reason to look at immersive art from another angle.

What can art do, then, in the current situation? There is no communal ethos or higher purpose - gods, in Heidegger's terms - that would measure and guide machinational thinking. It is not just that the gods are absent but that "the divine radiance has become extinguished in the world's history" (GA 5: 269/PLT 89) and the world has lost its "magic" (Zauber) (GA 55: 5o). This divine radiance or magic is what Heidegger also calls holiness (Heiligkeit): the ineffable plenitude and worth of beings that has been covered over by machinational thinking. At the same time, humans have become "mindless" (besinnungslos) - incapable of questioning themselves, of opening up to what is worthy of questioning.

In this situation, the poet's task is no longer, to use the later Heidegger's poetic idiom, to build "the house where gods come as guests," but simply to "lay out and secure the building site" (GA 4: 148/170) for such a house to be erected by future poets. In other words, the poet's task is to prepare for the possibility of the return of the gods. The verb "prepare" (vorbereiten) is vital here. The return of the gods is not something we humans can effectuate - indeed, such an attempt would lapse back into the metaphysics of subjectivity and power - but only something we can prepare for. What the poet can do is let others experience the "traces" (Spuren) of the holy that still remain in the world (GA 5: 272/

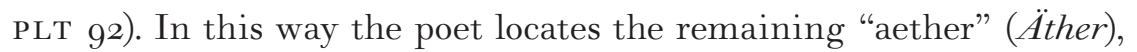
which the future gods need to live, and thus clears a space for their return (GA 5: 272/PLT 92). It is precisely the poet-and this effectively 
means artists in general (GA 5: 62/PLT 72) - who can do this, since art has the power to release things from everydayness and the calculative thinking through which we usually approach them, to let them come forth in their inexhaustibility and depth. This has the effect of making us realize that there is more to the world and our place in it than what machinational thinking lets us think. Even though being open to the inexhaustible plenitude of being does not directly tell us who we are, what to do with our lives, or what to expect from the future, as Greek art once did, we can keep faith that this intimation of holiness may prepare for the return of history-shaping purposes. ${ }^{26}$

In Basic Questions of Philosophy (1937-38), Heidegger formulates this relation to the world's plenitude in terms of wonder (Erstaunen). For Heidegger, being attuned to wonder is not just a question of being struck by something unusual, drawing pleasure from it, and then continuing living as if nothing has happened. Wonder is a transformative and allpervasive basic disposition (Grundstimmung), in which everything, even what is most usual and habitual, becomes unusual, and we see the world in a new light (GA 45: 172-73/149). Wonder fundamentally changes man's relation to the world as such by compelling him "to hold fast to beings as beings in pure acknowledgement" (GA 45: 174/15o), heeding to beings as they give themselves without reserve. Wonder is about being faced with the mysterious fact that there are beings rather than nothing, that beings are intelligible to us, and that we find ourselves inexplicably caught up in their midst. Such disposition is not "a melting into or a vague and empty wallowing in "feelings" - i.e. a lived experience - but primordial contact with the event of beyng, Ereignis, that first disposes humans to thinking (GA 45: 170, 172/147, 149; GA 65: 10).

The question then is, are immersive artworks capable of displacing viewers into wonder, or does the hold of Erlebnis-thinking prevent them from working in such a way? On the face of it, this suggestion is undermined by Heidegger's claim that we moderns are so deeply enmeshed in metaphysical modes of thinking that we are hardly able to encounter beings as something wondrous (GA 45: 184-85/159). Instead, we deal with beings "as the object of machination and of lived experiences" 
(GA 45: 185/159 tm). Artworks have become objects of amazement (Sichwundern) and marveling (Verwundern) - which Heidegger treats as synonyms - instead of wonder in its proper sense. When we marvel at something, he says, we savor its exceptional and exciting character, wanting to be "teased and fascinated" by the marvelous without trying to understand it, without it disposing us into the beginning of thinking (GA 45: 157-58/136-37). Because of modern man's "intoxication with lived experience" (Erlebnistrunkenboldigkeit), art has to devise ever new ways of producing experiences of amazement; for example, Heidegger points out how the film industry is driven by the audience's desire to be continually amazed (GA 45: 158, 162/137, 14,o). It would be easy to think that immersive art also addresses this taste for amazement instead of wonder and leave it at that.

To my mind, however, this is not all there is to immersive art. My claim is that immersive experience can be more than just wowexperiences. The "can" here indicates a possibility that some artworks in some conditions can fulfill, and not a necessity that every immersive artwork realizes. First, I have elsewhere argued at length that immersive experiences are experientially transformative, by which I mean that they can alter the perceiver's sense of time, space, selfhood, and relation to other beings. ${ }^{27} \mathrm{At}$ best, immersive artworks undermine the perceiver's capacity to anticipate and control the work, taking her by surprise. The immersive artwork transports the viewer into a foreign world, which has its own logic and its own laws, and which the viewer cannot control. It is the viewer who becomes caught up in the happenings of the work; it is, after all, a defining feature of immersive art that the viewer enters the work and does not apprehend it as an object from a distance. Immersive artworks thus fundamentally differ from the metaphysical determination of artworks as objects: due to their holistic character, immersive artworks are not something the perceiver can objectify, take hold of, and neutralize by setting it against a horizon of normality - in this sense their phenomenology differs from mere marveling (cf. GA 45: 172-173/149). Thus, I argue that such experiences of immersion cannot be faithfully described in terms of Heideggerian 
lived experience, as something far more radical is at stake in them. An immersive artwork, perhaps better than any other artform, can achieve the displacement (Verrückung) Heidegger values in art, where things are released from our usual - that is, machinational - way of attending to them and let come forth in their unusualness (GA 5: 54/PLT 64).

Secondly, immersive artworks can also be existentially transformative precisely on account of the experiential transformation they bring about. By this I mean a change in the basic disposition with which we relate to beings, a disposition that can spill over to the lifeworld after the immersive experience has dissipated. Heidegger argues in On the Essence of Truth (1931-32) that the essence of art lies in that it "possesses essential insight for the possible [das Mögliche], for bringing out the inner possibilities of beings, thus for making man see what it really is [das Wirklich-seiende] with which he so blindly busies himself" (GA 34: 64/47). The point here is that the way we comport ourselves in the world - i.e. position ourselves in it, interpret situations, interact with things and other people, etc. - is conditioned by our understanding of how the world works, in other words, by our sense of what is possible and what is not. This sense of the possible ${ }^{28}$ encourages certain ways of perception, thought, and action that inform the way we carry out our lives and relate to others in a given situation. Our sense of the possible never encompasses the whole horizon of possibilities, because the way we are oriented toward the situation at hand always discloses certain possibilities and covers over others. If this limitedness is not recognized, the sense of the possible can become experientially restricting and stultifying, as we do not understand our way of living as one possibility among many. Now, Heidegger argues that artworks are capable of illuminating otherwise unnoticed possibilities of experience and existence and thereby widen the sense of the possible.

Here immersive artworks come into the picture. I argue that precisely through their capacity to holistically - perhaps more holistically than any other artform - stimulate our cognitive, affective, imaginative, and bodily capacities, immersive artworks have the ability to transgress our common, usually unquestioned experiential modes. They can shake 
our conceptions of normalcy and expose us, in the safety of the artwork, to extraordinary experiential situations that we cannot anticipate or control. Take teamLab's work The Infinite Crystal Universe (2018), which takes the visitor into a cosmos of flickering lights. The work constitutes its own time-space, cut off from the actual world. Spatial coordinates - up and down, left and right - lose their meaning, a sense of distances dissolves, and the body's understanding of possible action is altered, as the situation is so unlike any normal life situation. The work feeds the imagination by concretizing an experiential space we could normally only dream of. There is a sense of floating in space, though gravity still keeps our feet on the ground. The work obeys its own laws, foreign to the accustomed logos of quotidian life. I think such experiences very concretely disclose that one belongs to a richer world that offers more possibilities than one has heretofore realized, throwing into relief the usually unnoticed meaning structures of the everyday. ${ }^{29}$ I can only speak from personal experience, but such artworks can endow a similar sense of cosmic gratitude that Heidegger associates with intimations of holiness. ${ }^{30}$ Such experiences can attune us into a questioning, wondrous rapport with beings that liberates us from the calculating, overpowering relation of machination. In this way, one could say, machination turns against itself, or, to use a more Heideggerian phrase, "somersaults beyond itself" (GA 6.1: 75/N1 77) in immersive art: the calculative thinking behind these works ends up, at least sometimes, producing experiences of wonder. ${ }^{31}$

There is also another way in which immersive art might turn out to be valuable in undermining the sway of machination. In Mindfulness, Heidegger claims that we are currently facing the task of preparing for a decision on "whether machination of beings would make man exceedingly powerful and transpose him into an unbridled being of power" or whether some other relationship with beings could gain a foothold (GA 66: $15 / 11 \mathrm{tm}$ ). Preparing for this decision requires that thinking becomes mindful "of the sway of power and of what is fundamentally effective in the self-overpowering of power" (GA 66: 20/15). In "The 
Question Concerning Technology" (1953), Heidegger suggests that it is especially art that is called to confront technological machination and bring to light the danger it harbors (GA 7: 35-36/QC T 34-35). My suggestion is that immersive art can, despite all appearances, answer this call very well.

So how can art disclose the predominance of machination in modernity? In Heidegger's view, if we grow to understand how machination delimits our ways of producing and experiencing art, we can also come to understand the overpowering nature of machination as a whole. ${ }^{32} \mathrm{An}$ artwork can embody the obstructions to truth, not just the unfolding of truth. ${ }^{33}$ Here the blatantly manipulative character of immersive art can turn out to be a medicine in addition to a poison: though their illusions of being in another world might be strong, and though they usually hide the system operating behind the scene, immersive artworks cannot hide their own artificiality, as their theatrics are often so obvious one can hardly miss them. For example, consider teamLab's recent work Continuous Life and Death at the Crossover of Eternity (2020). The work takes the viewer inside a kaleidoscopic space filled with digital projections of blooming flowers. If the viewers touch the projected flowers, their petals scatter, but if they stay still, the flowers begin to grow more abundantly. On the face of it, the work seems to be a banal metaphor for the human relationship to nature, but the work also lends itself to a more interesting interpretation. The almost magical interaction between the work and viewer is achieved with a program that monitors the viewer's movements and renders the projections in real time. It is impossible not to notice that the viewer's interaction with the flowers which can be taken to stand for nature as a whole - is mediated, or even constructed, by a complex computer program. The work, unwittingly or not, thus comments on the way technology mediates our relationship with our environment to the extent that it has become almost a naturalized aspect of this relationship in the sense that we are no longer aware of it.

Likewise, the Rain Room, which enables audiences to experience a rather unnatural form of rain, "speaks not only of our desire to control nature but also of our dependence upon science and technology to understand and occupy it, of our condition of being always already 
immersed within a media-technological condition for which Rain Room is a symptomatic reflection." ${ }^{134}$ Though such artworks as the Rain Room and Continuous Life and Death at the Crossover of Eternity constitute their own worlds, they are not isolated from the lifeworld of the audience. Through such immersive works, the audience can become mindful of the technological character of modern art and of how it turns artworks into experience machines. The earlier claim that immersive art does not disclose anything about the lifeworld, as it tears the viewer away from the lifeworld by opening another world, thus needs to be elaborated: precisely by opening another world, by implication, immersive artworks can make the viewer mindful about the sway of machination in the lifeworld.

What about the earth? Does an immersive artwork disclose an earth? After all, Heidegger holds that the greatness of an artwork is not measured solely by its capacity to set up a world, but also by the way it sets forth the earth, the sensory-elemental dimension of being that sustains the world but is irreducible to it. A Greek temple, for example, draws up the luster of its rocky foundations, the sky above it, the light, the air - the elements that open up space for the Greek world. What about an immersive artwork? The elemental dimension that it discloses - and I am thinking here especially about contemporary digital installations - is what I would call the virtual. By this I mean the digitally produced sensuous "stuff," the "matter" of digital imaging, the pixels, patterns, matrices, and grids it involves. It is that which sustains and supports the virtual worlds we interact with while surfing the Internet, using social media, or playing video games. The virtual has two distinctive features in relation to the other "earthly" elements that support the lifeworld: first, it is not just manipulable by techno-scientific thinking $g^{35}$ but is wholly produced by such thinking, and second, it is incorporeal, in that it alone cannot sustain a physical world we could enter. As the presence of the virtual has become an important feature, or perhaps one of the defining features, of contemporary reality, two things have happened: first, the expansion of the lifeworld from the purely physical plane to the virtual, and second, the virtualization of the physical - or physicalization of the virtual - by recent technical developments. By the 
latter I mean the results of new imaging techniques, such as augmented reality and interactive digital projections, where the physical and the virtual intermingle to the extent that they are almost impossible to separate from each other - just consider, for example, how the 2016 mobile game Pokémon Go made millions of people roam around their surroundings in the hunt for digital creatures. Immersive artworks are very good at thematizing this virtual (or virtualized) "earth" upon which contemporary lifeworlds are built, further deepening the thematization of the technological condition of the contemporary era.

On the face of it, these two positive possibilities not only seem to contradict the claims of the previous section but also each other. First, how could an artwork be, at the same time, a source of both vacuous lived experience and wonder? Surely, it cannot be both at the same time. But, as I have claimed, marveling and wonder come quite close to each other in that both involve an extraordinary experience, and, depending on the perceiver's attunement, an immersive artwork might function just as a source of marveling or as a source of wonder. Much depends, as Heidegger points out, on the person's readiness to "sustain" (aushalten) and "carry out" (vollziehen) a change in her disposition by "accepting what overgrows" her, i.e. by letting herself be moved to wonder (GA 45: 174-75/151).

Second, how could an artwork catch viewers in the sway of Ereignis and at the same time make them mindful of the artificial character of the event? Again, I do not believe it can, if the term "at the same time" is taken to mean simultaneity - for an awareness of the constructed nature of immersion would, I believe, effectively destroy the experience of immersion. However, our dealings with art are not restricted to singular and homogeneous experiences. On the contrary, aesthetic experiences usually involve, in the big picture, at least two phases: a deeply engaged (should I say immersive) phase and a more distanced reflective phase. Even if, at one moment, we might be completely caught up by an artwork, oblivious of our surroundings, of the passage of time, and even of ourselves, these moments are usually fleeting and evaporate quickly, only to leave us detached from the work and able to reflect on what 
just happened. This is usually very poignant with immersive artworks: even if we submit to them, we can also detach ourselves from them and reflect on how they managed to pull our strings. Furthermore, what for one person is awe-inspiring might be calculating for another. An illustrative example of how an artwork can be so different for different people can be found in Heidegger's discussion with Tezuka Tomio, as reported in the text "A Dialogue on Language between a Japanese and an Inquirer" (1953-54), where they briefly discuss Akira Kurosawa's film Rashomon (1950). In striking contrast to the critique of cinema in Mindfulness, Heidegger claims the film brings forth "the enchantment of the Japanese world, the enchantment that carries us away into the mysterious," whereas Tomio sees it as an example of "the Europeanization of man and of the earth" (GA 12: 99/ow L 16). The film thus turns out be Janus-faced, in that it seems both to remedy the ills of Western modernity and to be afflicted by those very ills, depending on which way one looks at it. The very same condition seems to apply to immersive art as well. Consequently, I do not think the second objection has much force either.

We should thus reckon with the possibility that immersive art harbors the potential to undermine machination from within. This optimism, however, needs to be tempered with a few caveats. Much of the transformative potential of immersive art depends on the extent to which these works render visible the forms of machination they employ and thereby denaturalize the techno-scientific mediation so ubiquitous not only in art but in everyday life. Furthermore, much also depends on the viewers of these works and the curatorial contexts within which they are presented, and the discourses around them. To quote Scott again, "repeatedly faced with technologies offering us the illusions of both free play and mastery, taking flight requires a more tactical understanding of such systems and their limits, their glitches, their possible - if momentary - openings." ${ }^{136}$ The question is: how can artists, curators, and audiences learn to employ such a tactical understanding of immersive art? 


\section{CONCLUSIONS}

In a late text titled "Technik und Kunst-Ge-stell" (ca. 1953), Heidegger once again returns to the question of what and how can art be in an era of machination. He concludes that art is "not a form of organization, but an opportunity for measure-giving and steady mindfulness." ${ }^{37} \mathrm{In}$ the first half of this article, I argued that immersive art, as the culmination of machinational Erlebniskunst, promotes mindlessness. It is also a prime example of technology's measureless capacity to manipulate the world and even to create new worlds. Nonetheless, the very same aspects that provoke these criticisms could be seen as constituting immersive art's ability to promote "measure-giving mindfulness" - first by eliciting experiences of wonder, and then by drawing our attention to the machinational means by which these experiences are achieved. Immersive art could thus be seen not only as the culmination of machination but as the point where machination becomes self-overcoming. Heidegger's thinking supports the frequent criticism that immersive art is a superficial trifle, art for the age of Instagram, but also points beyond such criticism toward heretofore little-appraised positive aspects of immersive art. In this way, I argue, Heideggerian thinking beautifully captures the ambiguities and complexities inherent in current immersive art. At the same time, the case of immersive art shows how Heideggerian thinking remains fruitful for theorizing at least some aspects of contemporary art. 


\section{NOTES}

\section{Acknowledgments}

This work has been supported by the Kone Foundation. I thank Lee Braver and Jussi Backman for their extensive comments on this article.

1 This is how immersive art is usually defined in art journalism; cf., for example, Corinne Anderson, "How and Why Immersive Experiences Are Taking Over the Denver Art Scene", 303 Magazine, January 8, 2020, https://30zmagazine.com/2020/o1/immersiveart-denver-colorado/. Theoretical literature, on the other hand, has a large variety of overlapping concepts, such as "absorption," "recentering," "immersion," "aesthetic illusion," and "transportation" that all refer to the experience of going to another world (cf. chapter 2.1 in Werner Wolf, "Illusion (Aesthetic)", The Living Handbook of Narratology, last modified January 17, 2014, https:// www.lhn.uni-hamburg.de/node/71.html). I will here stick to the term "immersive" because it has become standard in the artworld. It is nevertheless good to bear in mind that theoretically relevant considerations on immersive art can be found under different terminologies.

2 See, for example, "Huge Visitor Turnout Prompts Amos Rex to Mull Pre-bookings," YLE, January 2, 2019 (https://yle.fi/uutiset/osasto/news/huge visitor turnout prompts amos rex to mull pre-bookings/10579404) or Jori Finkel, "A Matter of Time: How Long Do You Really Need in Yayoi Kusama's Infinity Mirrored Rooms?," The Art Newspaper, November 20, 2017 (https://www.theartnewspaper.com/comment/a-matter-of-timehow-long-would-you-spend-in-yayoi-kusama-s-infinity-mirroredrooms).

3 There has, however, been some recent interest in the phenomenology of immersion and its role in contemporary art. See, for example, Gertrud Koch, Die Wiederkehr der Illusion: Der Film und die Kunst der Gegenwart (Berlin: Suhrkamp, 2o16), Simon 
Høffding, A Phenomenology of Musical Absorption (Cham: Palgrave Macmillan, 2018), and Harri Mäcklin, Going Elsewhere: A Phenomenology of Aesthetic Immersion (PhD Dissertation, University of Helsinki, 2018).

4. See Katharine Schwab, "Art for Instagram's Sake," The Atlantic, February 17, 2016, https://www.theatlantic.com/ entertainment/archive/2016/02/instagram-art-wonder-renwickrain-room $/ 463173 /$, and Joanne Ostrow, "There's a Lot of Buzz around 'Immersive' Experience in Art, Theater and Entertainment. But Is It Art?," The Colorado Sun, January 18, 2019, https://coloradosun.com/201g/ol/18/immersive-experiences-are-they-art/.

5 Nosheen Iqbal, "From High Art to Tipsy Night Out: Has Immersive Theatre Sold Its Soul?," The Guardian, February 2, 2020, https://www.theguardian.com/stage/2020/feb/02/ high-art-tipsy-night-out-immersive-theatre-lost-its-soul.

6 Elena Foulidis, "How Masterpieces Are Reduced to Brands - A Review of the Immersive Van Gogh Exhibit," The Varsity, July 23, 2020, https:/thevarsity.ca/2020/07/23/how-masterpieces-arereduced-to-brands-a-review-of-the-immersive-van-gogh-exhibit/.

$7 \quad$ Foulidis, "How Masterpieces Are Reduced to Brands."

8 Ray Mark Rinaldi, "Art and the Active Audience: Participatory Art Changes the Audience's Role from Viewer to Doer," The Denver Post, December 31, 2012 , https://www.denverpost. $\mathrm{com} / 2012 / 12 / 31 /$ art-and-the-active-audience-participatory-artchanges-audience-role-from-viewer-to-doer/.

9 Heidegger does sometimes use language that refers to immersion, as in "Origin," where the artwork is said to occur as a displacement (Verrückung) in the presence of which "we were suddenly somewhere else than we usually tend to be" (GA 5: 21, 54/PLT 35, 64). This, however, is not to be understood as immersion in the sense of the term I am using here: the happening of truth in art discloses the world and earth we already inhabit and does not take us to another world. Furthermore, Heidegger seems to equate immersive experiences - in the sense of going to another world 
- with lived experiences (Erlebnisse) in his discussion of Wagner (GA 6.1: 84-87/N1 85-88). Of course, Heidegger's mediations on everydayness (Alltäglichkeit) as a mode of Dasein's existence in Being and Time could be interpreted as a phenomenology of immersion, but this should not be too hastily equated with the phenomenology of aesthetic immersion. See Jussi Backman, Harri Mäcklin, and Raine Vasquez, "Editors' Introduction," Journal of Aesthetics and Phenomenology 4, (2017): 93-99.

11 See Jussi Backman and Timo Pankakoski, "Relativism and Radical Conservatism" in The Routledge Handbook of Philosophy of Relativism, ed. Martin Kusch (London: Routledge, 2019), 219-227. Martin Heidegger, "Die Unumgänglichkeit des Da-seins ('Die Not') und die Kunst in ihrer Notwendigkeit (bewirkende Besinnung)," Heidegger Studies 8 (1992): 6-12, at 8.

13 G.W.F. Hegel, Werke in 20 Bänden mit Registerband, Band I3: Vorlesungen über die Ästhetik I (Frankfurt am Main: Suhrhkamp, 1986), 25 .

14. Julian Young, Heidegger's Philosophy of Art (Cambridge: Cambridge University Press, 2001), 43, 105-11.

15 See also Young, Heidegger's Philosophy of Art, 8-9.

16 Martin Heidegger, "Technik und Kunst-Ge-stell" in Kunst und Technik: Gedächtnisschrift zum Ioo. Geburtstag von Martin Heidegger, ed. Walter Biemel and Friedrich-Wilhelm von Herrmann (Frankfurt am Main: Klostermann, 1989), xiii-xiv, at xiii.

17 Felicity Scott, "Limits of Control: Rain Room and Immersive Environments," Artforum 52 (2013), https://www.artforum. $\mathrm{com} / \mathrm{print} / 201307 /$ limits-of-control-rain-room-and-immersive-environments-4,2636.

18 Cf. B. Joseph Pine II and James H. Gilmore, The Experience Economy (Boston: Harvard Business School Press, 1999).

19 Young, Heidegger's Philosophy of Art, 95.

20 Scott, "Limits of Control: Rain Room and Immersive Environments." 
Lise Arlot, "Feel It, Live It: Immersive Art," $M e$ dium, August 2, 2017, https://medium.com/feral-horses/ feel-it-live-it-immersive-art- $8 \mathrm{~g} 6 \mathrm{~d} 76$ zee $2 \mathrm{bz}$. I am using the Husserlian term "lifeworld" to refer to what Heidegger calls simply "world" in order to distinguish the world we usually inhabit from the "virtual" world of the artwork.

23 Young, Heidegger's Philosophy of Art, 64-68.

24. "Nur noch ein Gott kann uns retten," Der Spiegel, May 31, 1976: $193^{-219}$, at 219 .

25 Young, Heidegger's Philosophy of Art, 94-96.

26 Young, Heidegger's Philosophy of Art, 4,2-43, 125.

27 I argued this at length in Mäcklin, Going Elsewhere, chapters 3 and 4 .

28 I borrow this term from Hanna Meretoja, The Ethics of Storytelling (Oxford: Oxford University Press, 2017).

29 Young, Heidegger's Philosophy of Art, 130-33.

3o See note 14 .

$3^{1} \quad$ For more general discussions on the relationship between art and wonder in Heidegger, see Young, Heidegger's Philosophy of Art, 107, Jeff Malpas, Heidegger and the Thinking of Place (Cambridge, MA.: The MiT Press, 2012), 255-57, and Detlev Lüders, "Der 'Zauber der Welt' und das heutige 'Chaos': Heidegger und die moderne Dominanz des Dürftigen," Heidegger Studies 17 (2001): 21-43.

$3^{2}$ See Friedrich-Wilhelm von Herrmann, "Technik und Kunst im seynsgeschichtlichen Fragehorizont" in Kunst und Technik, 25-46, and George Kovacs, "Heidegger's Directives in Mindfulness for Understanding the Be-ing-historical Relationship of Machination and Art", Heidegger Studies 24 (2008): 39-59.

33 Kovacs, "Heidegger's Directives," 57.

34. Scott, "Limits of Control."

35 An essential aspect of the earth, in Heidegger's view, is that it eludes all scientific and technical attempts to take hold of it (GA 5: 33/PLT 45-46). Interestingly, the virtual also sometimes exhibits moments of such resistance, for example when systems glitch and 
fail to operate as planned. An immersive artwork can, wittingly or not, thematize such glitches; like a hammer that becomes conspicuous only in breaking (GA 2: 93, 100/sz 69, 75), a controlling system reveals itself in malfunctioning. For example, in the aforementioned article "Limits of Control," Felicity Scott points out that the Rain Room's failure to function as it should makes it all the more interesting: "Although most accounts repeat the claim that you walk into a field of water without getting wet, for many visitors, including myself, the system fails, just slightly, at keeping them dry. Even if you don't run, mechanisms occasionally lag and drops of water hit you; something unscripted happens that may or may not be the result of your behavior. The system exhibits what appears to be a degree of noise or entropy, an unanticipated effect that is presumably undesirable, but which actually produces a nominal encounter with the work."

$3^{6}$ Scott, "Limits of Control."

37 Heidegger, "Technik und Kunst - Ge-stell," xiv. 